Chapman University

Chapman University Digital Commons

History Faculty Articles and Research

History

2-7-2017

\title{
Challenging the Myth of Italian Jewish Assimilation
}

Shira Klein

Follow this and additional works at: http://digitalcommons.chapman.edu/history_articles

Part of the European Languages and Societies Commons, and the Jewish Studies Commons 


\section{Challenging the Myth of Italian Jewish Assimilation}

Comments

This is a pre-copy-editing, author-produced PDF of an article accepted for publication in Modern Judaism - A Journal of Jewish Ideas and Experience following peer review. The definitive publisher-authenticated version

Klein, Shira. "Challenging the Myth of Italian Jewish Assimilation." Modern Judaism - A Journal of Jewish Ideas and Experience 37, no.1 (2017): 76-107. doi:10.1093/mj/kjw022.

is available online at DOI: $10.1093 / \mathrm{mj} / \mathrm{kjw} 022$

Copyright

The author 


\section{Shira Klein}

\section{CHALLENGING THE MYTH OF ITALIAN JEWISH ASSIMILATION*}

There is a widespread belief that Italian Jews in the modern period “'assimilated,” meaning that they merged with the gentile society to such an extent that they abandoned their Jewish identity. This belief is based on the fact that modern Italian Jews became less observant. From the nineteenth century onwards, Italian Jews attended synagogue less frequently, observed kashrut less stringently, and married Christians in growing numbers. Most scholars have concluded from these trends that Italian Jewish identity disintegrated. This article argues to the contrary. Using a wide array of sources, including Italian Jewish community archives, newspapers, memoirs, and oral histories, it shows that the Jews of modern Italy maintained their distinctiveness from nonJews and invented entirely new forms of Jewish culture. From the late nineteenth century until World War II, the Italian Jewish communal system consolidated and centralized. Jewish leaders harnessed state laws to strengthen their communities, and established national organizations where none had stood before. A growing Jewish newspaper industry fostered the sense of belonging to a Jewish collective. Women and girls participated in Jewish public life more than in the pre-modern period. Religious practice developed in dynamic ways as Italian Jews, like their German and French brethren, introduced reforms. Jewishness found expression in daily life through domestic religious practices, life-cycle events, and culinary

customs. In all these ways, Italian Jews forged a modern Jewish identity.

\footnotetext{
* This is the final draft of Shira Klein's article “Challenging the Myth of Italian Jewish Assimilation,” which appeared in Modern Judaism 37 (1), January 2017, p 76-107.
} 


\section{THE CASE FOR ASSIMILATION}

The idea that modernity led to the disintegration of Jewishness began over a century ago. In the 1890s, the Russian Jewish historian, Simon Dubnov, argued that emancipation, the process that granted Jews political and civic equality, threatened to corrode Jewish culture, particularly in Western and Central Europe. Jews in these areas, he warned, were nearing “'national assimilation”, that would eventually “impel Jews to merge with other nations - and Judaism would disappear."1 This paradigm ruled supreme for decades. Scholars, particularly of Eastern European origin, described the Jews of France, Germany, Austria, and Britain, as communities on the path to losing their Jewish distinctiveness. Russian-born historian Ben-Zion Dinur led this argument in the 1950s. Modern Western Jews, Dinur posited, had gone down a path of "selfnegation.’' With only “a minimal degree of Jewishness,” they had become “a diffused minority with no clearly distinct way of life ... [and] only the very vaguest traces of the ancestral heritage.”2 Galician-born Raphael Mahler repeated this view in the 1970s. The French Revolution, he wrote, although it signaled the start of emancipation on the continent, "heralded a period of national disintegration and assimilation.”3

Scholars of Italian Jewry joined this line of thinking. Focusing on the rise of mixed

\footnotetext{
${ }^{1}$ Simon Dubnow, History of the Jews, vol. IV (South Brunswick: T. Yoseloff, 1971), 82. See also Frankel, “Introduction,” Jonathan Frankel et al., eds., Assimilation and Community: the Jews in Nineteenth-Century Europe (Cambridge: Cambridge University Press, 1992), 13.

${ }^{2}$ Ben-Zion Dinur, Be-Mifneh Ha-Dorot : Mehkarim Ve- iyunim Be-Reshitam Shel Ha-Zemanim Ha-Hadashim BeToldot Yisra'el (Jerusalem: Bialik, 1955), 31, 50. The translation is Jonathan Frankel’s.

${ }^{3}$ Raphael Mahler, A History of Modern Jewry, 1780-1815 (London: Vallentine Mitchell, 1971), xxii-xxiii.
} 
marriages and the decline of strict observance, they stated that Italian Jews shed their Judaism in the modern period. "The impact of emancipation upon the internal life of Italian Jewry was ... deleterious," wrote British-Jewish historian Cecil Roth in 1946, for “assimilation had made appalling progress.” Roth described Jewish culture in Italy as “'wasted," “'dwindled to vanishing point," “"neglected," and "pathetic." ${ }^{4}$ Italian scholars, both Jewish and non-Jewish, made the same argument. In 1962, non-Jewish historian Renzo De Felice published his seminal Storia degli Ebrei Italiani. Reprinted in seven editions and translated into English in 2001 as The Jews in Fascist Italy, this book claimed that the twentieth century saw the "rapid and massive assimilation of the Italian Jews, morally and materially, into Italian society.’' This attachment, De Felice held, "caused a repudiation of their own Jewishness, as if being Jews meant that they were not able to be completely Italian.” ${ }^{5}$ In his 1963 Storia degli Ebrei in Italia [The History of the Jews in Italy], Jewish historian Attilio Milano charged modern Italian Jews with “drowsiness.” When emancipation abolished the ghettos, he opined, it also destroyed " a wall against external influences ..., a rock protecting [Jewish] individuality, traditions, and culture.”' Emancipation “corroded"' Jewish culture and “slackened” Jewish ties, Milano stated. ${ }^{6}$ Italian-American historian Andrew Canepa agreed with this argument, positing in 1977 that post-emancipation Italian Jewish history was one of "conversions and absorption ... [which] determined the triumph of the assimilationist conception. ${ }^{\text {" }}$ In 1986, Mario Toscano, a much-cited scholar of modern Italian Jewry, wrote that

\footnotetext{
${ }^{4}$ Cecil Roth, The History of the Jews of Italy (Philadelphia: JPS, 1946), 504-506.

${ }^{5}$ Renzo De Felice, Storia Degli Ebrei Italiani Sotto Il Fascismo (Torino: Einaudi, 1962), 17.

${ }^{6}$ Attilio Milano, Storia Degli Ebrei in Italia (Torino: Einaudi, 1963), 357, 379.

${ }^{7}$ Andrew Canepa, "L'atteggiamento Degli Ebrei Italiani Davanti Alla Loro Seconda Emancipazione: Premesse E
} 
“the awareness of Jewish identity wavered"' after emancipation. ${ }^{8}$ By the late nineteenth century, Toscano claimed, "Judaism was reduced to a mere religious dimension and took on negative, archaic, backward, restrictive connotations.",9

In the 1980s and 1990s, scholars of Western and Central European Jewry, but not of Italian Jewry, began to challenge the Dubnovian axiom. New research questioned whether postemancipation Jewish identity had, in fact, withered. Marsha Rozenblit, in her 1983 book The Jews of Vienna, borrowed a term from American sociologist Milton Gordon when she argued that Vienna’s Jews “acculturated,” that is, they absorbed the norms and culture of the majority group but maintained certain distinctive Jewish features. She posited that Viennese Jews did not “assimilate," a term implying the abandonment of ethnic particularity. ${ }^{10}$ In 1992, Jonathan Frankel and Steven Zipperstein's edited volume, Assimilation and Community, further challenged Dubnov's claim. In the words of David Sorkin, a contributor to the volume, the idea that “emancipation begat assimilation” simply was not true. ${ }^{11}$ Historians of German Jews, such as

Analisi," Rassegna Mensile di Israel 43(1977): 436.

${ }^{8}$ Mario Toscano, "Gli Ebrei in Italia Dall'emancipazione Alle Persecuzioni," Storia contemporanea 17, no. 5 (1986): 913.

${ }^{9}$ __ Life in Italy, ed. Vivian B. Mann (Berkeley: University of California Press, 1989), 30.

${ }^{10}$ Marsha Rozenblit, The Jews of Vienna, 1867-1914 : Assimilation and Identity (Albany, NY: SUNY Press, 1983), Introduction. See also — Reconstructing a National Identity: The Jews of Habsburg Austria During World War I (NY: Oxford University Press, 2001), 23-28. Milton Gordon, Assimilation in American Life: The Role of Race, Religion, and National Rights (NY: Oxford University Press, 1964), Chapter 3.

${ }^{11}$ David Sorkin, “The Impact of Emancipation on German Jewry” in Frankel et al., Assimilation and Community: 
Sorkin and Marion Kaplan, and of French Jews, such as Paula Hyman, Esther Benbassa, and Lisa Leff, made a similar point, while Israel Finestein did the same for British Jewry. ${ }^{12}$ By the early 2000s, a revision had occurred within the field, firmly concluding that modern Jewish culture in Central and Western Europe had developed but not disintegrated. In the words of Enlightenment scholar Lois Dubin, “Jewish community persisted, but in changed forms.” 13

In the field of Italian Jewish history, no such revision occurred. Scholars in the 1990s, and indeed to this day, continued to argue that Italian Jewish identity crumbled in the modern period. Sergio Della Pergola, a demographer, wrote in 1993 that Italian Jews in the modern period underwent a “rapid process of merging and assimilation," resulting in "irreversible erosion”' of Jewish culture.. ${ }^{14}$ Two years later, political scientist Dan Vittorio Segre wrote of the "rapid

the Jews in Nineteenth-Century Europe, 177.

12 David Sorkin, The Transformation of German Jewry, 1780-1840 (New York: Oxford University Press, 1987). Marion A. Kaplan, The Making of the Jewish Middle Class: Women, Family, and Identity in Imperial Germany (New York: Oxford University Press, 1991). Paula Hyman, The Jews of Modern France (Berkeley: University of California Press, 1998), Chapter 4. Esther Benbassa, The Jews of France: A History from Antiquity to the Present (Princeton, NJ: Princeton University Press, 1999), 124-133. Lisa Moses Leff, "Jewish Solidarity in NineteenthCentury France: The Evolution of a Concept," Journal of Modern History 74, no. 1 (2002): 33-34. Israel Finestein, “Jewish emancipationists in Victorian England: Self-Imposed Limits to Assimilation,” in Frankel et al., Assimilation and Community: the Jews in Nineteenth-Century Europe.

${ }^{13}$ Lois Dubin, "Enlightenment and Emancipation," in Modern Judaism: An Oxford Guide, ed. Nicholas de Lange and Miri Freud-Kandel (Oxford: Oxford University Press, 2005), 39.

${ }^{14}$ Sergio Della Pergola, "Precursi, Convergenti, Emarginati: Trasformazioni Demografiche Degli Ebrei in Italia, 1870-1945," in Italia Judaica: Gli Ebrei Nell'italia Unita (Roma: Ministero per i Beni Culturali e Ambientali, 1993), 64. 
disintegration of Italian Jewry," and claimed that the Italian Jewish press of the late nineteenth century was “anemic, conformist, and defensive, fighting a lost battle against assimilation.” ${ }^{15}$ In 1998, historian Gadi Luzzato Voghera acknowledged that Italian Jewish intellectuals had produced a rich literary culture in the nineteenth century, but bemoaned what he considered a "substantial disorientation and loss of identity”' among Italian Jews. ${ }^{16}$ He lamented the "substantial cultural impoverishment suffered by the Italian Jewish communities in the nineteenth century." ${ }^{17}$ Sara Reguer agreed with this point in her history of Italian Jews. "In the encounter between the Jewish and Italian cultures,” she wrote in 2013, “it was inevitable that the Jewish one would succumb to the Italian one., 18

In the last few years, however, a handful of historians have begun to move away from the assumption that Italian Jews lost all sense of ethnic particularity. More attuned to the revisions in scholarship regarding other European Jews, these scholars have hinted at the continuing distinctiveness of Italian Jews after emancipation. Cristina Bettin stated in her book, Italian Jews from Emancipation to the Racial Laws (2009), that "the Jew of that period [1870-1938] was

${ }^{15}$ Dan V. Segre, "The Emancipation of Jews in Italy," in Paths of Emancipation: Jews, States, and Citizenship, ed. Pierre Birnbaum and Ira Katznelson (Princeton, NJ: Princeton University Press, 1995), 234.

${ }^{16}$ Gadi Luzzatto Voghera, Il Prezzo Dell'eguaglianza: Il Dibattito Sull'emancipazione Degli Ebrei in Italia, 17811848 (Milano: F. Angeli, 1998), 179.

17 , "Italian Jews," in The Emancipation of Catholics, Jews, and Protestants: Minorities and the Nation State in Nineteenth-Century Europe, ed. Rainer Liedtke and Stephan Wendehorst (Manchester, UK: Machester University Press, 1999), 183.

${ }^{18}$ Sara Reguer, The Most Tenacious of Minorities: The Jews of Italy (Boston: Academic Studies Press, 2013), 116. 
integrated, rather than assimilated, into Italian society.”19 Elizabeth Schächter, in The Jews of Italy (2011), similarly critiqued the term "assimilation," calling it an "inadequate... analytical tool” for studying Italian Jews. ${ }^{20}$ Carlotta Ferrara degli Uberti’s Fare Gli Ebrei Italiani [The Making of Italian Jews] (2012) traced the anxieties of nineteenth-century Italian Jewish leaders regarding their communities' loss of Judaism, and argued these were exaggerated concerns. ${ }^{21}$ These three historians have questioned the assumption that Italian Jews abandoned their Judaism after emancipation, but fall short of dispelling it completely. The following pages examine Jewish identity in modern Italy, clarifying that Italian Jews maintained their sense of Jewishness following emancipation. Italian Jewish culture was not static; it developed and evolved, beginning with a centralization of Jewish communal organizations.

\section{THE TRANSFORMATION OF JEWISH COMMUNAL LIFE}

The modern period ushered in a new self-conception for Jews in the Italian Peninsula. For the first time, they began to regard themselves as a countrywide, Italian-Jewish collective, not just as local, towncentered collectives. This change was rooted in a transformation of the Jewish communal framework which began with Napoleon's invasion of the peninsula in 1796. Before the French troops arrived, Jewish communities throughout the peninsula had functioned as insular

\footnotetext{
${ }^{19}$ Cristina M. Bettin, Italian Jews from Emancipation to the Racial Laws (New York: Palgrave Macmillan, 2010), 72.

${ }^{20}$ Elizabeth Schächter, The Jews of Italy, 1848-1915: Between Tradition and Transformation (London: Vallentine Mitchell, 2011), 3.

${ }^{21}$ Carlotta Ferrara degli Uberti, Fare Gli Ebrei Italiani : Autorappresentazioni Di Una Minoranza (1861-1918) (Bologna: Il Mulino, 2011), 64, 151, 213.
} 
geographical units with no formal links to one another. Jewish governance depended on the local gentile ruler and varied from one community to the next. Napoleon's troops heralded a dramatic change. In addition to abolishing the ghettos and granting Jews full social, political, and economic rights (known as the “First Emancipation’”), Napoleon installed the French “consistory” system which established the same community structure throughout the regions he conquered. Under this system, every large community elected three notables, a grand rabbi, and a rabbi. For the duration of the French occupation, therefore, the Italian Jewish communities assumed a uniform model of governance. ${ }^{22}$

Napoleon's changes lasted only as long as his reign, ending with his defeat in 1815 . The ensuing Congress of Vienna marked the start of the Restoration period, reinstated the preNapoleonic duchies, kingdoms, and Papal States, and expanded Austria's control over the northeast of the peninsula. With the old rulers came the old restrictions, some of them herding Jews back into the ghettos, and the communities went back to functioning as isolated organizations with varying forms of governance and no formal ties to one another. The communities of Casale Monferrato and Turin, for instance, elected their leaders. In the Tuscan towns of Pisa, Livorno, Siena, and Pitigliano, Jewish leaders were nominated for life by the non-Jewish ruler. In Rome, the consistorial system collapsed but no new law replaced it. In Trieste, then under Austrian rule, the Jewish community had total autonomy of governance, and its council elected a rabbi every three years. ${ }^{23}$ The elements shared by Jewish communities in all

these towns were an exclusively male leadership, some form of community income-whether

${ }^{22}$ Guido Fubini, La Condizione Giuridica Dell'ebraismo Italiano (Torino: Rosenberg \& Sellier, 1998), 28-36.

23 , Condizione Giuridica, 28-29. Guido Bachi, "Il Regime Giuridico Delle Comunita' Israelitiche in Italia

Dal 1848 Ai Giorni Nostri," Rassegna Mensile Di Israel 12, no. 7-9 (1938): 205, 230. 
taxes or voluntary dues — and a range of Jewish institutions and services, such as synagogue prayer, education, welfare, and burial.

The push toward centralizing and standardizing the communities resumed when Jewish emancipation returned to the table in the 1840s. This "Second Emancipation" grew out of the Risorgimento, or "'Reawakening,"' the nationalist movement that strove to bring the peninsula under a unitary Italian state. Favoring a more liberal government, Risorgimento leaders advocated equality for religious minorities. They rallied around King Carlo Alberto, monarch of the House of Savoy and ruler of Piedmont, who agreed in 1848 to grant Jews equal rights as part of his new constitution. When the monarchy expanded and became the Kingdom of Italy in 1861, those rights spread to Jews elsewhere in the realm. By 1870, Italy's 36,000 Jews, just over a tenth of a percent of the Kingdom's 29 million Italians, had become equal citizens. ${ }^{24}$

The twin processes of Italian unification and Jewish emancipation spurred Jewish communal leaders to unite. Just as the Kingdom of Piedmont moved to unify the peninsula under one crown, the Jews of Piedmont sought to unify the Jewish communities into one system. It was no coincidence that the Jews of Turin—Piedmont's capital—led this structural change. In 1848, Turin's Chief Rabbi, Lelio Cantoni, outlined the transformation needed for the Jews. All the Jewish communities in the realm, he suggested, would follow the same governance, elect leaders in the same way, and impose the same kind of taxes. An umbrella organization headquartered in Turin would oversee the communities.. ${ }^{25}$ Although Cantoni’s proposal to centralize Italian Jewry mirrored Italian unification, it was no simple mimicry of gentile society. He also followed the

\footnotetext{
${ }^{24}$ For an overview of emancipation in Italy, see Roth, History, Chapters 9-10. Milano, Storia, 338-369.

${ }^{25}$ Lelio Cantoni, Nuovo Ordinamento Del Culto Israelitico Nei Regi Stati (Torino: G. Cassone, 1848), 69-78.
} 
French Jewish model of the consistory. ${ }^{26}$ The idea of uniting Italian Jews was " validated by the example offered by the organization of Jewish religion in France," he wrote. "We propose [to run the communities] as in France.”27

The centralization of the Jewish communities proceeded gradually. In 1857, Cantoni’s supporters proposed a law which was approved by Minister of Interior Urbano Rattazi. The thirtyarticle Rattazzi Law established one set of rules for all Jewish communities in the kingdom. All Jews would henceforth belong automatically to the community where they resided, and would pay it an obligatory income tax. "Every community is governed by an administrative Council elected by the community's male members who are contributors [of the tax], who are of age, and who can read and write,"' stipulated the law. ${ }^{28}$ This legislation applied to Piedmont, Liguria, Emilia, Marche, and part of Tuscany. ${ }^{29}$ From the state's perspective, the regulation of Jewish communal income was consistent with laws passed in 1843 and 1855 that regularized the income of the Waldensian religious minority and the Catholic Church. ${ }^{30}$

Where the Rattazzi Law applied, Jewish communities became similar to one another and more centralized. The law did not extend to the communities of Lombardy, the Veneto, Rome, or

\footnotetext{
${ }^{26}$ Hyman, The Jews, 44-46, 52.

${ }^{27}$ Cantoni, Nuovo Ordinamento, 24, 58.

28 “Legge per la riforma degli ordinamenti amministrativi ed economici del culto israelitico ne’ regii stati,” July 4 1857, reprinted in L'Educatore Israelita, 1857, p. 168-172, Article 6.

${ }^{29}$ Bachi, "Il Regime," 197-204.

${ }^{30}$ Francis Messner, Public Funding of Religions in Europe (Surrey: Ashgate, 2015), 149.
} 
several cities in Tuscany, regions that the kingdom annexed only after passing the new law. ${ }^{31}$ Some of these communities practiced a more liberal form of membership whereby Jews could choose whether or not to belong to the community and pay its taxes. Since such communities found their coffers dwindling, however, most of them eventually adopted reforms reminiscent of the Rattazzi Law. The community of Florence is a case in point. In the 1860s it took the liberal path, letting its members decide whether or not they chose to pay taxes. When the community's income dropped from 53,227 lira in 1868 to 25,447 lira in 1898, its leaders installed an obligatory taxation system in the style of the Rattazzi Law. ${ }^{32}$ With time, the communities in the peninsula increasingly resembled one another. ${ }^{33}$

Italian Jewish leaders in the late nineteenth and early twentieth centuries continued their efforts to unite with one another. In 1863 in Ferrara, for the first time in the peninsula's history, they organized a congress representing communities across the kingdom. For almost a week, delegates from thirty-one communities discussed issues such as self-governance, funding, religious instruction, and protection from Catholic proselytizing. They strove to find common ground, as would befit communities living in a unified kingdom. "The unity of Italian Judaism is a sacred tribute to the unity of Italy," stated one delegate at the meeting. ${ }^{34} \mathrm{~A}$ second meeting followed four years later in Florence. In 1911, Italian Jews set up a formal umbrella organization,

${ }^{31}$ Bachi, "Il Regime," 205-233.

$32 \ldots$ _ "Il Regime," 210.

${ }^{33}$ Fubini, Condizione Giuridica, 42-43, 46.

34 Yoseph Colombo, "Il Congresso Di Ferrara Del 1863," Rassegna Mensile Di Israel 36, no. 7/9 (1970): 82-83, 93. 
the "Consortium of the Italian Jewish Communities.", 35 The Consortium, stated its leaders, “intends to represent Italian Judaism . . . and aims to be an element of union and common interest."36

Under Fascism, Italian Jewish leaders continued to move away from compartmentalized, region-specific identities, toward a peninsula-wide Jewish culture. In 1930, three Jewish notables - the chief rabbi of Rome, Angelo Sacerdoti, the president of the Roman Jewish community, Angelo Sereni, and Turin-born jurist, Mario Falco-collaborated with government officials to pass a new law. Like the Rattazzi Law that it replaced, the 1930 law formalized the community tax by asserting that Jews would be subscribed to a community at birth, and would have to pay its taxes unless they actively dissociated themselves from it. Unlike the Rattazzi Law, however, this legislation applied to the entire peninsula and provided for a national Jewish organization, a “'Union of Italian Jewish Communities.’' The Union replaced the Consortium. During the 1930s, the Union appealed to the government on behalf of all the communities, brought community delegates together for nationwide meetings in Rome, and collected levies from each community. A new rabbinical council, elected by rabbis and councilors, oversaw all rabbis in the country. ${ }^{37}$

\footnotetext{
${ }^{35}$ Schächter, The Jews of Italy, 63-76, 85-89. Roth, History, 347-348, 365-366, 494-495. Renzo De Felice, The Jews in Fascist Italy : A History (New York: Enigma Books, 2001), 93.

36 5-26-13 Consortium circular, quoted in Stefania Dazzetti, L'autonomia Delle Comunità Ebraiche Italiane Nel Novecento : Leggi, Intese, Statuti, Regolamenti (Torino: G. Giappichelli, 2008), 19.

${ }^{37}$ Royal Decree Law 10-30-30, n. 1731; Royal Decree Law 11-19-31, n.1561. See also _—_, "Gli Ebrei Italiani E Il Fascismo: La Formazione Della Legge Del 1930 Sulle Comunità Israelitiche," in Diritto Economia E Istituzioni Nell'italia Fascista, ed. Aldo Mazzacane (Baden Baden: Nomos, 2002). Michele Sarfatti, The Jews in Mussolini's
} 
Perhaps the most visible sign of the strength of the Jewish communities was that most Italian Jews in the nineteenth and early twentieth centuries rarely broke their ties with their communities. Nobody forced Italian Jews to stay members of a community, and it was certainly cheaper to leave given the community tax. The 1930 law stipulated a clear (though long) procedure to dissociate from a Jewish community. Yet most Italian Jews remained affiliated and enjoyed the privileges that came with that membership, including participation in religious services and burial in the Jewish cemeteries. In the early 1930s, an average of 165 individuals a year dissociated from the communities, less than half of a percent of the entire prewar Italian Jewish population. ${ }^{38}$ In one case, one Adolfo Camerini dissociated from the community of Florence in 1934, only to change his mind two years later. "I would like to return to be a part of the Community," he requested, promising to pay the annual tax. The community readily agreed. ${ }^{39}$

The change in Jewish governance was only one of several transformations that contributed to the continuation of a thriving Jewish communal life in modern Italy. Education and welfare were two other forms of communal activity that preserved Jewish distinctiveness. In the early modern period, Jewish boys had received their education from private tutors or in small boarding schools run within the homes of elite Jewish families, while Jewish girls had rarely received a

Italy: From Equality to Persecution (Madison: University of Wisconsin Press, 2006), 53-58. De Felice, The Jews, 93-98.

38 12-31-41 Memorandum, “Numero dei dissociate pervenuto all’unione dale comunità,” AUCEI, Fondo Attività UCII dal 1934, Serie Censimenti, b. 71B, f. 4, sf. Varie. See also Sarfatti, The Jews, 29. Roberto Bachi, L'evoluzione Demografica Degli Ebrei Italiani: 1600-1937 (Città di Castello: Tip. Unione arti grafiche, 1939), 188.

${ }^{39}$ 6-16-36 Adolfo Camerini to Jewish Community of Florence, ACEF, b. 59 (E.6.1) Unione delle Comunità Israelitiche, f. 5 “1936, U2, Unione delle Comunità Israelitiche Italiane”. 
formal education. ${ }^{40}$ In the nineteenth century, with the emergence of a modern school system in Italy and the spread of more enlightened ideas concerning women, Jewish communities opened modern schools, including girls' schools. The Florentine community, which had run a boys' school since 1646, began a girls' school in 1857. Their initiative received further impetus with the passing of the Casati Law of 1859 that established a standard curriculum for all Italian schools and a universal education for all boys and girls. ${ }^{41}$ Admittedly, Jewish schools did not attract the majority of Jewish schoolchildren. A survey conducted by Rabbi Elia Artom in 1912 showed that only 1,493 children, about a quarter of all Italian Jewish children aged six to fourteen, attended institutions of Jewish learning, while the rest attended non-Jewish secular schools run by the state. ${ }^{42}$ This signaled a decrease in Jewish education for boys, who had rarely attended gentile learning institutions prior to emancipation. In the case of Jewish girls, however, the opposite was true.

Jewish leaders protected Jewish education under the Fascist dictatorship, which introduced a sudden Catholicization of Italian schools. In 1922-23, to win Church support for the newborn

\footnotetext{
${ }^{40}$ Stefanie Siegmund, The Medici State and the Ghetto of Florence : The Construction of an Early Modern Jewish Community (Stanford: Stanford University Press, 2006), p. 159, 467. Howard Adelman, "The Educational and Literary Activities of Jewish Women in Italy During the Renaissance and the Catholic Restoration," in Shlomo Simonsohn Jubilee Volume, ed. Daniel Carpi (Tel Aviv: Tel Aviv University, 1993), 9-12, 23.

${ }^{41}$ Lorenzo Minio-Paluello, Education in Fascist Italy (London: Oxford University Press, 1946), 9-15. Perry Willson, Women in Twentieth-Century Italy (New York: Palgrave Macmillan, 2010), 15-16.

42 Elia S. Artom, La Scuola Ebraica in Italia (Firenze: Giuntina, 1913), Appendix. For total number of Jewish children, see Franco Eitan Sabatello, "Ha-Megamot Ha-Hevratiyot Veha-Miktso 'Iyot Shel Yehude Italyah, 18701970" (PhD Dissertation, Hebrew University, 1972), 65.
} 
regime, the Fascist government introduced religious content into state schools. Minister of Public Education Giovanni Gentile made religion classes compulsory in all primary schools, required children to recite the catechism in class, and obligated all schools to hang crucifixes on their classroom walls. ${ }^{43}$ "There have already been cases where students have been asked to recite a Catholic prayer in the middle of a class," worried one Jewish leader in $1923 .{ }^{44}$ Jewish communities responded to the Gentile reform by providing more Jewish schooling. [[The Roman Jewish community opened a new elementary school in 1925, while the Jewish community in Milan established a middle school several years later. ${ }^{45}$ In the late 1920s, the Jewish community of Trieste spent a quarter of its budget on Jewish instruction, more than on any other item. ${ }^{46}$ Many communities ran afternoon schools called Talmud Torà, teaching biblical texts and biblical Hebrew. In the 1920s, more than half of the Jewish children in Venice, some ninety boys and girls, attended the Talmud Torà. ${ }^{47}$ In 1931, the Union of Italian Jewish Communities persuaded the government to allow Jewish schools to remove Catholic content from their textbooks, a remarkable feat given the regime's jealous control over education. In the Jewish edition of the official textbook

\footnotetext{
43 Richard J. Wolff, "Catholicism, Fascism and Italian Education from the Riforma Gentile to the Carta Della Scuola, 1922-1939," History of Education Quarterly 20, no. 1 (1980): 5-8. Alessandra Minerbi, "Tra Nazionalizzazione E Persecuzione: La Scuola Ebraica in Italia, 1930-1943," Contemporanea 1, no. 4 (1998): 705.

44 “La Questione della Scuola,” Israel, 12-27-1923, p. 4.

45 “Corriere Triestino,” Israel 1-10-1929, p. 4.

${ }^{46}$ Simon Levis Sullam, Una Comunità Immaginata: Gli Ebrei a Venezia (1900-1938) (Milano: Unicopli, 2001), 107. Renata Segre, Gli Ebrei a Venezia, 1938-1945: Una Comunità Tra Persecuzione E Rinascita (Venezia: Il Cardo, 1995), p. 25 lists some 160 children aged 5 to 15.

${ }^{47}$ Minerbi, "Tra Nazionalizzazione," 710.
} 
almost half the pages were cut out, as were Catholic sentences from poems and prose. ${ }^{48}$

Jewish charity also continued in the modern period. It too underwent a process of centralization, like the Italian Jewish community system as a whole. In place of a multitude of fraternities and pious associations that had existed in the pre-modern period, some communities now consolidated their charitable functions under large umbrella organizations. In Rome, home to the largest and poorest Jewish population, the community established a "Central Delegation of Charity' ' in the 1880s to oversee all charitable Jewish associations in the capital. ${ }^{49}$ These included four large charities and twenty-six small agencies. ${ }^{50}$ In 1921, historian Giacomo Blustein reflected that the consolidation had helped the community. “'One single, great institution,” he reasoned, had enabled Roman Jews “to rearrange public charity and simplify its operation.", 51 This drive to make Jewish philanthropy more effective echoed similar developments in Germany. In Germany, however, the impetus for this change was the arrival of hundreds of thousands of impoverished Eastern European Jews. ${ }^{52}$ In Italy, where no mass immigration ever occurred, philanthropy remained geared only toward local Jews.

Italian Jewish leaders spent considerable resources from community taxes to aid less

\footnotetext{
48 Bachi, "Il Regime," 231.

49 Giacomo Blustein, Storia Degli Ebrei in Roma (Roma: Maglione \& Strini, 1921), 276-277. 50 _ Storia Degli Ebrei in Roma, 277.

51 Derek Penslar, "The Origins of Modern Jewish Philanthropy," in Philanthropy in the World's Traditions, ed. Warren Ilchman (Bloomington: Indiana University Press, 1998), 206. _—, Shylock's Children: Economics and Jewish Identity in Modern Europe (Berkeley: University of California Press, 2001), 122.

521949 booklet of Asili Infantili Israelitici di Roma, ASCER, Archivio Contemporaneo, b. 90, f. 1, Asili.
} 
fortunate Jews in the late nineteenth and early twentieth centuries. The Italian government had begun expanding social welfare as early as the 1880s, and extended help to the needy. But the government only added to the aid provided by Jewish communal institutions; it did not replace them. In the 1890s, for instance, the Roman Jewish community supported a home for poor Jewish children, which also benefitted from an annual subsidy from the state’s Treasury. ${ }^{53}$ In the 1930 s, when the Fascist regime set up a series of institutions to provide unemployment funds, pensions, family allowances, and health care, the Jewish community of Venice collaborated with the local branch of a national welfare agency to help destitute Jews. ${ }^{54}$ Larger communities like Rome, Turin, and Milan, continued to operate Jewish orphanages and old-age homes for Italian Jews with no one to care for them, as they had done before emancipation.

The argument that Italian Jews abandoned their Judaism assumes an ever-contracting Jewish public sphere. In the twentieth century, however, Jewish public life expanded to include

\footnotetext{
53 Jens Alber et al., "Modernization, Democratization and Development of Welfare States in Western Europe," in The Development of Welfare States in Europe and America, ed. Arnold J. Heidenheimer and Peter Flora (New Brunswick: Transaction Publishers, 2009), 57, 59. Maria Giovanna Pipino, "Istituzioni E Assistenza Pubblica in Italia Tra Fascismo E Repubblica: Gli Enti Comunali Di Assistenza - Parte I," Instoria: rivista online di storia \& informazione 25, no. LVI (2010), http://www.instoria.it/home/assistenza_pubblica_italia_I.htm. Maria Sophia Quine, Italy's Social Revolution: Charity and Welfare from Liberalism to Fascism (New York: Palgrave, 2002), especially p. 95, 108, 117. Levis Sullam, Una Comunità Immaginata, 81, note 35.

${ }^{54}$ Howard Adelman, "Italian Jewish Women," in Jewish Women in Historical Perspective, ed. Judith Baskin (Detroit: Wayne State University Press, 1991), 152-153. Siegmund, The Medici State, 147, 284, 404. Federica Francesconi, "Jewish Women in Eighteenth-Century Modena," in Across the Religious Divide, ed. Jutta Sperling (NY: Routledge, 2010), p. 191, 202 n. 4.
} 
more women. In the early modern period, women could not hold public office, and with the rare exception of charitable female confraternities, they had no organizations of their own. ${ }^{55}$ Jewish women remained excluded from community councils (and unmarried women could not even vote for the council) until after World War II. In the interwar period, however, Italian Jewish women established their own, parallel leadership, in the form of the Association of Italian Jewish Women, founded in $1927 .{ }^{56}$ As a nation-wide organization it contributed to further centralizing and unifying the Jews of Italy. The Association's activity echoed the trend of women's mobilization in the general Italian society. It is not by chance that the Association first formed in Milan, the heart of Italy’s feminist movement. ${ }^{57}$

Jewish women’s public activity grew at a dizzying speed. Beginning with just a handful of women, by 1937 the Association counted 1,334 members in twenty-three Jewish communities throughout the peninsula. ${ }^{58}$ Its members helped the poor. The Rome branch provided coats, used clothing, and fabrics for needy children, while the Venetian branch handed out school meals and

\footnotetext{
55 On women’s exclusion from community councils, see Royal Decree Law 11-19-31, n.1561, Section II, Article 4. Sarfatti, The Jews, 14. For an exception in 1920 in Venice, see Levis Sullam, Una Comunità Immaginata, 75-76, note 17. Monica Miniati, Le Emancipate: Le Donne Ebree in Italia Nel Xix E Xx Secolo (Viella, 2008), 230-231. On the Association of Italian Jewish Women (Associazione Donne Ebree D'Italia, or ADEI), see Adei: Dalla Nascita Ai Giorni Nostri, (Venezia: ADEI, 1971).

${ }^{56}$ Willson, Women in Twentieth-Century Italy, Ch. 2, 79-82.

${ }^{57}$ Evelina Polaccco, “La Fondazione e l’Attività nel Pimo Quinquennio,” Adei, 41.

58 11-12-35 ADEI circular, ASCER, Archivio Contemporaneo, b. 90, f. 13, ADEI. Levis Sullam, Una Comunità Immaginata, 81, note 35.
} 
shoes. ${ }^{59}$ Turin’s section recorded all kinds of donations in the early 1930s: “'2,600 lira for a piano for the Talmud Torah . . . 860 for a radio for the old people’s home . . 1,293 for toilet basins for the orphanage.’, ${ }^{60}$ The Association received its income from members’ dues, donations, and crafts fairs. ${ }^{61}$ Cesare Finzi from Ferrara recalled how his mother met with other members every Wednesday, made and sold crafts, and gave the proceeds to charity. ${ }^{62}$ Other women offered classes — sewing, gymnastics, or dance — and turned over their earnings to the Association. ${ }^{63}$ Like Jewish women in Germany and Austria, they combined pre-modern Jewish traditions of tzedakah, giving to the needy, with bourgeois views that deemed charity a more respectable occupation for women than paid work. ${ }^{64}$

The reorganization of the Italian Jewish communities, their efforts at providing education and welfare, and Jewish women's activity for their brethren, all provide evidence that Italian Jews retained a sense of Jewish particularity in the modern period.

591935 report listing the charity carried out since 1927 by the Turin branch of ADEI, AUCEI, Fondo Attività UCII dal 1934, Serie Enti Vari, b. 44B, f. 5.

${ }^{60}$ Undated [1927?] statute of ADEI, AUCEI, Fondo Attività UCII dal 1934, Serie Enti Vari, b. $44 B$, f. 6.

${ }^{61}$ Cesare Moisè Finzi, Qualcuno Si È Salvato: Ma Niente È Stato Più Come Prima (Cesena: Il ponte vecchio, 2006), 52.

62 Evelina Polaccco, “La Fondazione,” Adei, 32.

63 Kaplan, The Making, 193, 198, 226. Victoria De Grazia, How Fascism Ruled Women: Italy, 1922-1945

(Berkeley: University of California Press, 1992), 99. Alison Rose, Jewish Women in Fin De SièCle Vienna (Austin: University of Texas Press, 2008), 46-57. Rozenblit, The Jews, 150.

64 Paolo Murialdi, Storia Del Giornalismo Italiano: Dalle Gazzette a Internet (Bologna: Il Mulino, 2006), 46-47, 91, 95. 


\section{INNOVATIONS IN JEWISH CULTURE}

In the decades following emancipation, Italian Jewish culture flourished and expanded in a number of ways. One of these was Jewish media—newspapers and books—-that grew exponentially in the wake of emancipation. In the mid-nineteenth century, for the first time in history, an Italian Jewish press came into existence. It emerged as part of the general Italian and European newspaper industry, which grew rapidly in the late nineteenth century thanks to technological innovations in the printing industry. The country's unification and its growing literacy increased the national market for newspapers, while denser urban populations and a fast growing railroad system enabled newspapers to reach more people, faster, and more frequently than in the past. ${ }^{65}$

From 1845 until the 1938 race laws prohibited Jewish publishing, Italian Jews produced twenty-six weekly and monthly Jewish newspapers. Some of these fizzled out after several months or years, but others lasted decades. By the 1930s, Italian Jews could choose from seven Jewish periodicals. Most popular was the weekly Israel, meaning “Judaism” or “Jewry” in Italian. It began in 1916 in Florence and grew from four pages to eight and sometimes ten. In 1919, its editors began a children’s monthly, Israel dei Ragazzi (Youngsters' Judaism) and in 1925 they added a cultural supplement, La Rassegna Mensile di Israel (Monthly Survey of Judaism) with longer academic essays. ${ }^{66}$ The monthly magazine Davar (Word in Hebrew), established in Milan in 1932, featured fifty pages of both general and Jewish content, including a children's column with photographs and letters from young Jewish readers. Readership sizes remain unknown, but the

\footnotetext{
65 Attilio Milano, "Un Secolo Di Stampa Periodica Ebraica in Italia," Rassegna Mensile di Israel 12, no. 7-9 (1938): 124, 131, 134.

${ }^{66}$ La Nostra Bandiera 4-16-38, p. 7.
} 
speed at which new serials came out suggests there was a vibrant market for these productions.

Jewish newspapers enabled readers to feel part of a Jewish collective, as they relayed news of other Italian Jews. A single issue of Turin’s newspaper La Nostra Bandiera (Our Flag) from early 1938, for instance, described holiday celebrations in Ferrara, funerals in Bologna, a Jewish history lecture in Milan, and rabbinic ordinations in Livorno. ${ }^{67}$ Davar had a regular Jewish-news column entitled "'Mundanes." "In this column we tell about holidays, tea parties, betrothals, weddings, and other mundane events that took place in the month,' stated the editors. ${ }^{68}$ Israel had a similar column, "Here and There in Italy," which chronicled Jewish births and deaths, weddings, and Jewish charity events. ${ }^{69}$ Readers could learn about the lives of other Jews everywhere in the peninsula. "Salvatore Luria in Turin ... finished a degree in Medicine and Surgery," one issue reported. "Ameglio Fargion . . . graduated brilliantly in industrial chemistry." 70 These snippets gave Italian Jews the sense of being part of a larger group.

Newspapers promoted a peninsula-wide Jewish consumer market. “Traders! Professionals!' Israel called in 1916, “Publicize in Israel, it’s the only Jewish weekly in Italian, distributed in thousands of copies in all of Italy." ${ }^{71}$ Jewish businesses sought Jewish clients throughout the interwar period. The textile shop “Avigdor” promised readers the best drapes and carpets in Turin, while Giuseppe Terracina in Rome offered typewriters, calculators, and

\footnotetext{
${ }^{67}$ Davar, September 1933, p. 6.

68 “Qua e là per l’Italia,” Israel 1-13-16, p. 3. “Dalle Città d’Italia,” Israel 3-10-25, p. 7.

69 “Lauree,” Israel 7-25-35, p. 8.

70 “Commercianti! Professionisti!” Israel 3-16-16, p. 4.

${ }^{71}$ La Nostra Bandiera 4-16-38, p. 8. “Annunzi economici,” Israel 3-30-16, p. 3.
} 
duplicators (forbearers of photocopiers). ${ }^{72 ~ " D o ~ y o u ~ w a n t ~ g o o d ~ o i l ~ o f ~ t h e ~ p u r e s t ~ o l i v e ? ~ T r y ~ t h e ~}$ producer A. G. Luzzatti,'” advised an ad in the monthly Il Vessillo Israelitico (The Jewish Flag). ${ }^{73}$ Jewish physicians advertised their clinics to Jewish patients. Dr Giuseppe Nagar in Turin guaranteed the latest treatment of gastric ulcers, and Dr Giacomo Feldman publicized his clinic for pulmonary illness in Florence. ${ }^{74}$ A single issue of Israel in November 1922, contained twentyseven ads by Jewish businesses for silverware, linens, ship tickets, insurance, antiques, thermometers, sewing machines, porcelain, Persian rugs, and smoking pipes. ${ }^{75}$

Jewish newspapers also facilitated a Jewish job market, especially for unmarried Jewish women seeking work in Jewish households. "A lady in her forties who is an educated, able housewife, offers herself as company to a lady," said one ad in 1917. “An educated young lady seeks work, offering herself as companion [or] house overseer,", said another in 1929. “A woman in her thirties, serious, offers herself as governess for a small family,"' stated a third in $1935 .{ }^{76}$

The Jewish press encouraged Jewish matchmaking. Il Vessillo Israelitico’s “Matrimonial Announcements"' offered a free service to help people find Jewish spouses. Singles could send in a brief description of themselves that the newspaper would publish anonymously. Readers interested in a match could contact the editors for an introduction. Men stressed good jobs and a

\footnotetext{
${ }^{72}$ Front matter, Il Vessillo Israelitico, 1-31-1917.

73 Israel 3-9-16, p. 4. La Nostra Bandiera 4-16-38, p. 8.

${ }^{74}$ Israel 11-16-22, p. 8

75 “Annunzi economici,” Israel 9-24-17, p. 4. “Piccola pubblicità,” Israel 1-3-29, p. 4. “Piccola pubblicità,” Israel 5-9-35, p. 8.

76 “Annunzi Matrimoniali” Il Vessillo Israelitico, 1916, Fasc. I, p. 2.
} 
steady income. One man in 1917 wrote: "Extremely distinguished, degree-holder, government 10 worker, 39 years old, 5000 [lire income] annually, seeking to marry a young woman, extremely elite, graceful, cultivated, rather tall, slim, 23-25 years old, [with an] adequate dowry.', 77 Women, in turn, underlined their own domestic skills and income, as in this 1935 example: "Extremely distinguished female teacher in her forties, healthy, attractive, excellent family, furnished house, income 20,000, capital 50,000, alone, seeking to marry a colleague or academic immediately.",78 Alongside Jewish newspapers, the Italian Jewish book market flourished after emancipation. The decade from 1848 to 1859 saw the publication of only twenty-five Italianlanguage books on Jewish subjects. This number rose to 45 in the 1880s, 90 in the 1920s, and 112 in the 1930s. ${ }^{79}$ A new publishing house, Casa Editrice Israel, began in Florence soon after World War I. It published books specifically on Jewish topics, and the Jewish press both advertised and reviewed its books regularly. ${ }^{80}$ Given the tiny size of the Jewish population in modern Italy, the peninsula no longer served as the Jewish literary center it had been in the seventeenth century, when it had produced half of all Hebrew books printed in the world. ${ }^{81}$ But Jewish publications

77 “Piccola Pubblicità,” Israel 7-25-35, p. 8. Levis Sullam, Una Comunità Immaginata.

78 Numbers aggregated from Giorgio Romano, Bibliografia Italo-Ebraica: 1848-1977 (Firenze: Olschki, 1979), 1576.

79 Alessandra Minerbi, "La Comunità Ebraica Di Firenze," in Razza E Fascismo: La Persecuzione Contro Gli Ebrei in Toscana (1938-1943), ed. Enzo Collotti (Roma: Carocci, 1999), 120. See column “Libri e Riviste” in various Israel issues, such as Israel 3-30-16, p. 3.

${ }^{80}$ Adam Shear and Joseph Hacker, “Introduction,” in The Hebrew Book in Early Modern Italy, (Philadelphia: University of Pennsylvania Press, 2011), 8.

81 Michael Harris, History of Libraries of the Western World (Lanham: Scarecrow Press, 1999), 155-157, 218. 
were on the rise. Italian Jewish communities set up libraries in the early twentieth century, mirroring the spread of public libraries all over Europe ${ }^{82}$ Venice's Jewish library was open to readers every Wednesday afternoon, and registered 650 loans of 230 different

titles between 1929 and $1941 .^{83}$ Florence’s Jewish library dispatched books to every city in Italy and to the Italian colonies. ${ }^{84}$

Italian Jews' culinary culture underwent innovations as well, mixing old elements with new. The strict food laws of halacha had long dictated that Jews eat differently from their gentile neighbors. Although kashrut waned, ${ }^{85}$ Jewish culinary habits continued. Jewish cooking favored goose, a handy alternative to ham, and used plenty of olive oil so as to avoid mixing butter and meat. Italian Jewish food culture mirrored new developments in gentile eating habits, but in a way that bolstered their sense of Jewishness. Nineteenth-century Europe saw the emergence of restaurants, an institution born in Paris at the end of the previous century. Ristoranti, trattorie, and osterie spread in unified Italy. ${ }^{86}$ Echoing this trend, Jewish restaurants, guest houses, delicatessens, and specialty shops appeared in early twentieth-century Italy. They made use of the Jewish press to market themselves to Jews around the peninsula. In the small town of Casale Monferrato in 1917, no fewer than three Jewish shops vowed they made the best goose salami, sausages, and

\footnotetext{
${ }^{82}$ Levis Sullam, Una Comunità Immaginata, 151.

83 “La Biblioteca Ebraica Circolente,” Israel 6-16-32, p. 8.

${ }^{84}$ Roth, History, 504-506.

${ }^{85}$ Fabio Parasecoli, Food Culture in Italy (Westport: Greenwood, 2004), 30-31. Paolo Raspadori, Ospitare, Servire, Ristorare (Soveria Mannelli: Rubbettino, 2014), 27.

${ }^{86}$ Advertisements, Il Vessillo Israelitico, 1-31-17, p. 27.
} 
drumsticks. The Basevi family, who ran a guest house in Verona, advertised goose salami the whole year round. ${ }^{87}$ The Della Pergolas in Florence ran a kosher guest house and restaurant, twenty minutes' walk from the kosher butcher and delicatessen. ${ }^{88}$ In the 1920 s and 1930s, Jewish newspapers announced one Jewish eatery after another, such as "Weissberg's Kosher Restaurant in Venice,” “Lichtenstein’s Kosher Restaurant in Milan,” and “Achille Ancona: Special Manufacturer of Passover Sweets [in Ferrara].” Davar listed eleven Jewish restaurants across the peninsula in $1933{ }^{89}$

The first Italian Jewish cookbook came out in the interwar period, part of the boom in general Italian culinary literature ${ }^{90}$ Ines De Benedetti, a member of Padua’s Association of Italian Jewish Women, collected and compiled recipes from all over Italy. Her friend Lucia Levi chose the title, Hidden Poetry: Six Hundred Recipes from the Jewish Kitchen. The Passover section alone boasted thirty-six recipes, most of them for azzime, the unleavened bread (matzo) eaten on that holiday. There was fried azzime, azzime with wine, azzime cake, azzime cookies, and so on. The book was a tremendous hit. It sold out quickly, and in 1937 Ines began preparing material for a second edition, which would be delayed by the outbreak of World War II. ${ }^{91}$

\footnotetext{
${ }^{87}$ Israel 6-16-32, p. 8, advertisements. Israel dei Ragazzi 12-21-30, p. ii, advertisements. Il Vessillo Israelitico, 131-1917, front matter advertisements. Israel 6-1-34, p. 8 advertisements. Israel 3-10-25, p. 7 advertisements. 
Italian Jews found inventive ways to keep kosher. Precisely because they were like nonJews in most other areas of life, the decision to practice some form of kashrut held value for them. Every family articulated its own, often creative, rules. Lucia Bedarida’s family in Ancona, for instance, saw nothing wrong with using the same dishes for meat and milk, but refrained from eating pork. ${ }^{92}$ The Minerbi family in Ferrara, on the other hand, made sure to separate milk from meat, but did not mind eating pork, an allowance that would have appalled any rabbi. ${ }^{93}$ The Ascarellis in Ferrara avoided pork but ate rabbit, a meat also forbidden by Jewish law. ${ }^{94}$ Sergio De Benedetti’s grandfather in Florence diligently kept away from all forms of pork, with the exception of prosciutto, a dry-cured ham, which he simply could not do without. ${ }^{95}$ Similarly, the Vivantis in Mantua delighted in prosciutto served with melon and fried eggplant, but completely outlawed pork cutlets, pork roasts, and rabbit meat, and expressed horror at cooking with lard (pig fat). ${ }^{96}$ Sometimes the rules were invisible to anyone outside the family, as with the Polacco family in Ferrara, who consumed pork at other people's houses but avoided bringing it into their own

\footnotetext{
92 Testimony of Lot Minerbi, YVA, RG O.3, f. 10599.

93 Testimony of Aldo Ascarelli in Angelo Pezzana, ed. Quest'anno a Gerusalemme: Gli Ebrei Italiani in Israele (Milano: Corbaccio, 1997), 34.

${ }^{94}$ Debenedetti Sergio, "The Education of Sergio DeBenedetti, undated, unpublished manuscript, private papers of Vera DeBenedetti Bonnet, p. 2.

95 “Un ragazzo negli anni del razzismo fascista” by Corrado Vivanti, p. 4, ACDEC, Fondo vicissitudini dei singoli, b. 29, f. 942, Vivanti Corrado.

${ }^{96}$ Author’s interview with Anna Maria (Susi) Polacco, Buenos Aires, December 8, 2010, CU, Italian Jewish History Collection.
} 
home. ${ }^{97}$ In these intimate and home-centered acts, Italian Jews resembled their German brethren, who also engaged in what Marion Kaplan has called “domestic Judaism.," 98

Italian Jewish cultural programs grew in the twentieth century, echoing a general rise in leisure activities in Italy. ${ }^{99}$ Jews could choose from an increasingly rich variety of literary and artistic activities. A “Jewish Culture Committee”' emerged in Florence in 1907 and spread to other towns. Established by Galician-born Rabbi Shmuel Hirsch Margulies and supported by Triestine writer Dante Lattes, these committees promoted Hebrew, Jewish literature, and Jewish history. Margulies’s disciples organized nationwide Jewish youth congresses in 1911, 1912, 1914, and 1927. ${ }^{100}$ Jewish communities offered adult Hebrew classes and organized lecture series. Titles ranged from “"The Sabbath,” "'The Holidays,'” and “'The Prayers,” to “Judaism for Women and Women for Judaism," “"The Thought of Maimonides,” or “'When the Jew Jokes!” 101 Italian Jews attended concerts, plays, and exhibits, performed on community premises or in the Jewish schools. A Federation of Jewish Cultural Associations, begun in 1924, organized Jewish art displays that travelled up and down the peninsula, such as an exhibit of the famous Russian-born painter Abel

\footnotetext{
${ }^{97}$ Marion Kaplan, "As Germans and as Jews in Imperial Germany," in Jewish Daily Life in Germany, 1618-1945, ed. Marion A. Kaplan (New York: Oxford University Press, 2005), 237.

98 De Grazia, How Fascism, 201-203.

${ }^{99}$ Comitato Pro Cultura Ebraica. Schächter, The Jews of Italy, 210-211, 213-215, 219, 223. Bettin, Italian Jews, Chapter 3.

100 “Attività dei Circoli culturali,” Israel 1-10-1929, p. 2; “Dalle Città D’Italia,” Israel 1-3-1929, p. 4; “Dalle Città D’Italia,” Israel 3-10-25, p. 7.

101 “Attività dei circoli culturali,” Israel 1-10-1929, p. 2.
} 
Pann. It also collected, copied, and distributed Jewish music to communities nationwide. Livorno had its own Jewish theater company, which staged comedies and plays by foreign Jewish writers like Israel Zangwill, as well as by local Jewish playwrights. ${ }^{102}$

Italian Jews in the modern period embraced yet another new area of activity, namely, reaching out to co-religionists in Africa. In the early nineteenth century, most Jews in the peninsula had few ties to Jews in North Africa except for trade, which took place particularly through the port town of Livorno. ${ }^{103}$ In the age of imperialism, however, Italy took over stretches of Africa and after Italy invaded Libya in 1911-12, Italian Jews took a special interest in Libya's 24,000 indigenous Jews, most of whom lived in the cities of Tripoli and Benghazi. ${ }^{104}$ Just as Italy set out to “civilize”' Libyans, Italian Jews sought to rescue their North African co-religionists from their supposed backwardness. According to the Union of Italian Jewish Communities in 1934, Libyan Jews suffered from "'problems in all spheres of social, cultural and spiritual life,” and above all, "the absence of a spiritual guide to elevate the tone of that extremely important Community and lead it to a brighter destiny." The Union recommended exporting an Italian rabbi from the "motherland" to the colony. ${ }^{105}$ The Fascist state, recognizing that Italian Jews could help it to

102 Francesca Trivellato, "The Port Jews of Livorno and Their Global Networks of Trade in the Early Modern Period," Jewish Culture and History 7, no. 1-2 (2004). — , The Familiarity of Strangers : The Sephardic Diaspora, Livorno, and Cross-Cultural Trade in the Early Modern Period (New Haven: Yale University Press, 2009), Chapter 4.

103 Roberto Bachi, "Gli Ebrei Delle Colonie Italiane: Note Statistiche Sul Censimento 1931," Rassegna Mensile Di Israel 10, no. 9-10 (1936): 387.

${ }^{104}$ Sarfatti, The Jews, Appendix 2, p. 233-234.

105 Maurice M. Roumani, The Jews of Libya: Coexistence, Persecution, Resettlement (Portland, Ore.: Sussex 
Italianize its colonial subjects, appointed Aldo Lattes from Livorno as Chief Rabbi of Libya in 1937. ${ }^{106}$

Concern for Jews in Africa formed a new aspect of Italian Jewish culture. Italian Jews treated the Jews of Libya as “'belonging”' to Italian Jewry, similar to the way French Jews viewed their co-religionists in French-ruled Algeria. ${ }^{107}$ The Italian Jewish newspaper Israel covered Jewish activity in Benghazi and Tripoli in the same way it reported on Jewish news in Florence or Venice, as part of its news column "From the Cities of Italy." 108 The Association of Italian Jewish Women set up branches in Tripoli and Benghazi. ${ }^{109}$ Italian Jews encouraged Libyan Jews to pursue an Italian education, and rejoiced when several students from Tripoli enrolled in Florence's Rabbinical College in 1929. ${ }^{110}$

Another new aspect of Italian Jewish culture was Zionism. It served to reinforce the Jewish identity of a small but vocal group of Italian Jews. In 1901, a handful of Italian Jews founded the Italian Zionist Federation, the Italian branch of the world-wide Zionist Organization. Zionism never attracted a majority of Italian Jews before World War II, but it was a movement on the rise,

Academic Press, 2008), 22.

${ }^{106}$ Hyman, The Jews, 81-85.

107 “Dalle Città d’Italia,” Israel 7-25-35, p. 7. “Cronache Tripolitane,” Israel 1-3-1929. p. 4.

108 “Corriere Milanese,” Israel 4-10-33, p. 7. Evelina Polaccco, “La Fondazione,” Adei, 27-28.

109 “Inaugurazione del convitto annesso al Collegio Rabbinico Italiano,” Israel 1-3-1929, p. 3.

${ }^{110}$ Undated [1934] memorandum by Leone Carpi for the Unione dei Sionisti Revisionisti, CZA, RG A433, Alfredo Sarano collection, b. 3. Schächter, The Jews of Italy, Chapter 5. Augusto Segre, "Sionismo E Sionisti in Italia (19331943)," in Scritti in Memoria Di Nathan Cassuto, ed. David Cassuto (Gerusalemme: Kedem, 1986). 
growing to an average of 1,500 subscribers in the 1930 s (from a community of about 45,000 Jews). ${ }^{111}$ The Federation's secretary, Dante Lattes, also the editor of the weekly Israel, helped recruit new members. Israel provided constant news about Jewish life in Palestine and Zionist developments worldwide.

Zionist-minded Italian Jews rarely immigrated to Palestine, but that did not prevent them from being active in the peninsula. They focused on fund-raising and cultural programs, like Zionists in other central and western European countries. ${ }^{112}$ Several dozen youths attended Zionist summer camps in the 1930s. Another few dozen went on tourist cruises to Palestine, like Ettore and Anna Rieti, a doctor and a teacher, who in 1935 boarded a ship to Tel Aviv and visited

Bethlehem and Hebron. ${ }^{113}$ The Italian Zionist Federation organized five such tours in the 1920s and 1930s. ${ }^{114}$ Still others opted for philanthropy, either by helping eastern European Jewish refugees get to Palestine, or by assisting the Jewish poor there. The Association of Italian Jewish Women, which affiliated itself with the Women's International Zionist Organization (WIZO), sent money regularly to Palestine and in 1933 helped found a children’s home in Rehovot. “This year too,” the Association proudly reported in 1933, “[we] send WIZO the notable sum of 29,500 lira,

\footnotetext{
${ }^{111}$ Ezra Mendelsohn, On Modern Jewish Politics (New York: Oxford University Press, 1993), 57-59.

112 Anna Colombo, Gli Ebrei Hanno Sei Dita: Una Vita Lunga Un Secolo (Milano: Feltrinelli, 2005), 78.

113 Arturo Marzano, Una Terra Per Rinascere: Gli Ebrei Italiani in L'emigrazione in Palestina Prima Della Guerra (1920-1940) (Genova: Marietti, 2003), 61-66.

114 “Corriere Milanese,” Israel 4-10-33, p. 7. See also Undated [1927?] statute of ADEI, AUCEI, Fondo Attività UCII dal 1934, Serie Enti Vari, b. 44B, f. 6.
} 
for . . . clinics, nurseries, centers for maternity, [and] agricultural schools." ${ }^{115}$ Zionist activity provides further evidence that Italian Jews in the modern period experimented with new ways to express their Jewish identity.

\section{MODERNIZING RELIGIOUS PRACTICE}

Those who say modern Italian Jews "assimilated" point mainly to their declining religious observance. There is more than a grain of truth to this charge. Italian Jews in the nineteenth and twentieth centuries, just like their counterparts in Germany and France, moved away from the rigorous observance of their ancestors. ${ }^{116}$ They stopped closing their shops on Saturday, the traditional Jewish day of rest. They stopped going to synagogue daily as their parents and grandparents had done. As the nineteenth century drew to a close, synagogues had difficulty assembling even a weekly minyan, the quorum required to hold services. By 1900, Italian Jews rarely attended services more than two or three times a year.

Rabbis in the early twentieth century worried that religion was on the wane. In 1916, the Rabbi of Parma Donato Camerini despaired of the meager weekly synagogue attendance. "Is it possible that Jewish men who find the time for so many good or bad or vain things," he asked, “can’t find time once a week for the Torah?”"117 That same year Anselmo Colombo in Rome declared that, "assimilation, which has already set its roots within us, [will] soon ... invade the

\footnotetext{
${ }^{115}$ Hyman, The Jews, Ch. 4; Michael Meyer, Response to Modernity: A History of the Reform Movement in Judaism (Detroit: Wayne State University Press, 1995), 171. Kaplan, "As Germans," Ch. 17.

116 “Qua e là per l’Italia,” Israel 3-2-16, p. 3.

117 “Facciamo Le Ebree” by Anselmo Colombo, Il Vessillo Israelitico 1916 (n. XIX-XX), p. 508-509.
} 
entire body of Italian Judaism." ${ }^{118}$ Complaints continued into the 1930s when thirty rabbis from all over Italy issued a reprimand to Jews who failed to go to synagogue. "Brother reader or sister reader," they wrote in a 1937 pamphlet, “if by chance you belong to the ranks of these wayward ones, then these pages are written especially for you." ${ }^{119}$ These laments and entreaties give the impression that Italian Jews had indeed turned their backs on Judaism.

In fact, Italian Jews did not abandon their religion. Religion scholar Arnold Eisen notes that Jews after emancipation performed fewer religious practices than in the past, but that this fact did not correspond to lesser religious conviction. "Thrice-yearly services in the synagogue," writes Eisen, “along with a handful of annual celebrations in the home, were seen to 'encapsulate,' and so to legitimately replace, the fuller calendar of practice." Italian Jews, like the French, German, and English Jews studied by Eisen, “contracted the scope of Jewish practice” but still “retain[ed] a measure of distance from the larger society.", 120 This "distance” from their nonJewish surroundings, expressed through religious practices, is what kept Italian Jews Jewish.

Italian Jewish synagogue attendance is a fine example of the high value they placed on religious practice, however infrequent. Most commonly, Italian Jews went to synagogue on Rosh Hashanah, Yom Kippur, and Passover, as well as for life-cycle events. They spent less time in synagogue than their ancestors had done, but precisely because synagogue attendance no longer formed a daily or a weekly activity, Italian Jews regarded it as a special practice. Memoirs suggest

118 “I Rabbini d’Italia ai loro fratelli, Jamim Noraim 5698” (Bologna: Tipografia Zamperini \& Lorenzini, 1937), cited and translated in Sarfatti, The Jews, Appendix 3, p. 251.

${ }^{119}$ Arnold Eisen, Rethinking Modern Judaism: Ritual, Commandment, Community (Chicago: University of Chicago Press, 1998), 93, 117.

120 Olga Neerman, Ebrei Per Caso (Venezia-Mestre: n.p., 2010), 25-26. 
that the synagogue represented an important place for Italian Jews, one worthy of careful preparation. Olga Neerman described the first time she visited a synagogue, in 1931. “ No doubt the synagogue had to be a particularly important place,’’ recalled Olga, “'because [that] morning, mother dressed me in the little blue wool dress with the honeycomb embroidery. . . and decorated my hair with a satin ribbon ... Proud of such elegance ... I made my first entrance into the ... synagogue.’, 121 On the few times a year that Enzo Tayar and his family attended Florence’s synagogue, they too smartened up for the occasion. The children dressed in their festive sailor suits and their mother dabbed herself with cologne. ${ }^{122}$

Italian Jews expressed their religion less rigorously than their ancestors but, as far as they were concerned, it was not less meaningful. Whereas pre-modern Jews understood religious ritual to be a duty, notes Eisen, modern Jews increasingly viewed it as a "leisure-time pursuit that ornaments and adorns life.," 123 Post-emancipation Italian Jews conceived of religious practices just so, as acts of pleasure and beauty. On the rare occasions Mario Castelnuovo Tedesco attended synagogue services in interwar Florence, he perceived the act as a deeply spiritual one. "When at noon the sun filtered through the windows colored in yellow and blue,"' he recalled, "and the doors of the Holy of Holies [the Torah Ark] opened and the Bible came out covered in old and precious cloths, decorated in silver, I was in a dream of oriental splendor and I

\footnotetext{
${ }^{121}$ Enzo Tayar, Days of Rain (NY: Yad Vashem, 2004), 12.

${ }^{122}$ Eisen, Rethinking Modern Judaism, 85.

${ }^{123}$ Mario Castelnuovo-Tedesco et al., Una Vita Di Musica: Un Libro Di Ricordi, vol. 1 (Fiesole: Cadmo, 2005), 434.
} 
almost saw the old temple of Jerusalem destroyed for centuries.", ${ }^{124}$ Memo Bemporad experienced similar emotions when he attended the same synagogue. "The atmosphere and the ceremonies in the temple swept me away," he described, “and gave me an infinite sense of sweetness and happiness.", 125

Children, in particular, experienced the synagogue as a joyous place, even on the somber occasion of Yom Kippur. They looked forward to Birkat Kohanim, the Priestly Blessing, at which time the family patriarch would cover his family with the prayer shawl. When the blessing began, remembered Alberta Levi from Ferrara, “[the] children took advantage of the occasion to wink under the fringes of the large shawl. ${ }^{126}$ Bruno Colombo from Turin recalled the excitement with which he and his twelve cousins anticipated the benediction, crowded under the fabric, laughing and joking with each other. ${ }^{127}$ The Vivanti family from Mantua called themselves “assimilated”, Jews, but never missed going to synagogue on Yom Kippur. They too hurried to get there in time for Birkat Kohanim. ${ }^{128}$

${ }^{124}$ Memo Bemporad, La Macine: Storia Di Una Famiglia Israelita Negli Ultimi 60 Anni Di Vita Italiana (Rome: Editore Carucci, 1984), 18.

${ }^{125}$ Maria Marotta et al., La Storia Di Alberta (Napoli: Loffredo Editore, 2003), 12. See also Giorgio Bassani, The Garden of the Finzi-Continis (London: Quartet Books, 1978), 32-34.

${ }^{126}$ Testimony of Bruno Colombo in Chiara Bricarelli, ed. Una Gioventù Offesa: Ebrei Genovesi Ricordano (Firenze: Giuntina, 1995), 57.

127 “Un ragazzo negli anni del razzismo fascista” by Corrado Vivanti, p. 4, ACDEC, Fondo vicissitudini dei singoli, b. 29, f. 942, Vivanti Corrado.

${ }^{128}$ L. Scott Lerner, "The Narrating Architecture of Emancipation," Jewish Social Studies 6, no. 3 (2000): 1-5. Roth, History, 361. Carol Krinsky, Synagogues of Europe: Architecture, History, Meaning (Cambridge, Mass.: MIT Press, 
Italian Jews did not attend synagogue often but nevertheless took pride in their houses of prayer. They built grand edifices to house their synagogues, like other European Jews in the period after emancipation. ${ }^{129}$ The synagogue of Florence, inaugurated in 1882 and still standing today, boasts an elegant pathway and garden, an imposing pink and white stone façade, and a large dome covering a spacious prayer hall. A gold-blue color scheme decorates the interior, and frescos and mosaics cover the walls. Turin's Jewish leaders commissioned such a large synagogue building that they ran out of funds in the middle of construction and had to sell it to the municipality. Next they built what became Turin's Great Synagogue, inaugurated in 1884. It has onion-domed towers, massive granite columns, and a prayer hall capable of seating 1,400 people. ${ }^{130}$ The community of Rome similarly erected its new synagogue in 1904, with an imposing symmetrical complex and a square dome painted as a rainbow. ${ }^{131}$ Synagogue interiors displayed antique ritual art objects, from silver candelabras to embroidered curtains for the Torah Ark. ${ }^{132}$

Like their French and German brethren, modern Italian Jews practiced “eclectic patterns of observance,"’ namely, they picked and chose the customs that they wanted to maintain. They

1985), 59-92.

${ }^{129}$ Samuel Gruber, "Italian Synagogue Architecture and Italian-Jewish Identity," in The Most Ancient of Minorities: The Jews of Italy, ed. Stanislao G. Pugliese (Westport, CT: Greenwood Press, 2002), 173-174.

${ }^{130}$ Annie Sacerdoti et al., Italy: Jewish Travel Guide (Brooklyn, NY: Israelowitz Pub., 1993), 40-42, 140. Umberto Fortis, Jews and Synagogues: Venice, Florence, Rome, Leghorn; a Practical Guide (Venezia: Edizioni Storti, 1973), 85-87, 108.

${ }^{131}$ See photographs in Vivian B. Mann, Gardens and Ghettos: The Art of Jewish Life in Italy (Berkeley: University of California Press, 1989), 24, 31, 278.

132 Eisen, Rethinking Modern Judaism, 2, 91, 117. 
were convinced that through these traditions, however partial, they were carrying on the essence of their ancestors' faith. ${ }^{133}$ In the same way that they followed imaginative kosher rules, Italian Jews found creative ways to honor the Sabbath. Ora Kohn's parents in Turin permitted her to take the streetcar and attend school on Saturdays, but they themselves made a point of resting. Saul Ventura's father, a government official in Milan, had to work on Saturdays, but tried to avoid writing. ${ }^{134}$ The Zargani family in Turin marked Saturday by avoiding ham on that day, although they ate it during the rest of the week. ${ }^{135}$ In Genoa, Giorgio Pavia’s parents attended synagogue on Saturdays even if they drove the car to get there. ${ }^{136}$ The Benaim family had no compunctions about going to the cinema on Saturday afternoons, but sent the maid to buy the tickets so they would avoid handling money on the Sabbath. ${ }^{137}$ In these countless little rules, self-imposed and often self-invented, Italian Jews showed their respect for the Sabbath in ways often unseen by anyone outside the family.

In the late nineteenth and early twentieth centuries, Italian Jewish rabbis introduced religious reforms. Although they never went the path of Germany, where the official movement of Reform Judaism spread rapidly and amid loud controversy, ${ }^{138}$ Italian rabbis did make far-reaching

133 Testimony of Shaul Saul Ventura Ben Tora, YVA, RG O.3, f. 8335.

134 Aldo Zargani, For Solo Violin: A Jewish Childhood in Fascist Italy, a Memoir (Philadelphia, PA: Paul Dry Books, 2002), 120.

135 Author's interview with George Pavia, New York, September 24, 2009, CU, Italian Jewish History Collection.

136 Elisa Benaim Sarfatti, Un Racconto Molto Personale (Florence: Del Giglio, 2007), 14.

137 Meyer, Response to Modernity, Ch. 3, p. 142, p. 429 n. 152.

138 _ 
changes. They did so quietly and with no dramatic schism, continuing officially to subscribe to Orthodoxy. Italian Jewish reform resembled that of French Jews, who transformed their religious practices without ever declaring a new religious movement. ${ }^{139}$ Italian rabbis and cantors changed their apparel to suit Judaism's more visible and accepted status in Italy. They began to dress in distinguished, solemn gowns and large hexagonal hats adorned with a pompon. ${ }^{140}$ Rabbis and Jewish intellectuals translated Jewish scriptures into Italian, making them more accessible to a community no longer versed in Hebrew. Giuseppe Levi translated parts of the Talmud in 1861, and Samuel David Luzzatto translated the Bible between 1866 and $1875 .{ }^{141}$ Italian rabbis revived the idea of making music in the synagogue, a practice that had flourished in the seventeenth century and then diminished. ${ }^{142}$ In the spirit of modernization, Jews in the mid-nineteenth century introduced choirs and organs into their synagogues. They employed musical directors to train and conduct the choristers, most often children from the community, and some rabbis allowed women

139 Asher Salah, "How Should a Rabbi Be Dressed? The Question of Rabbinical Attire in Italy from Renaissance to Emancipation," in Fashioning Jews: Clothing, Culture, and Commerce, ed. Leonard Greenspoon (West Lafayette, Ind.: Purdue University Press, 2013), p. 9, p. 10 figure 18, and p. 12.

${ }^{140}$ Marco Di Giulio, "Resisting Modernity: Jewish Translations of Scripture and Rabbinic Literature in MidNineteenth-Century Italy," Modern Judaism 35, no. 2 (2015): 203-205, 207-208.

${ }^{141}$ Shlomo Simonsohn, "Some Disputes on Music in the Synagogue in Pre-Reform Days," Proceedings of the American Academy for Jewish Research 34(1966): 104-105, 110.

142 Edwin Seroussi, "Singing Modernity: Synagogue Music in Nineteenth- and Early Twentieth-Century Italy," in Acculturation and Its Discontents: The Italian Jewish Experience between Exclusion and Inclusion, ed. David Myers (Toronto: University of Toronto Press, 2008), 171. 
to perform in the choirs and prayer services. ${ }^{143}$ The new synagogues included raised pulpits for rabbis to deliver sermons, which became a central feature of services.

In contrast to pre-modern times, Italian Jews in the late nineteenth and early twentieth centuries displayed their religion in public. They staged enormous ceremonies, replete with musical interludes, sermons and speeches, and invited non-Jews to attend. When a Jewish banker's son married in 1894, the community of Alessandria held a splendid ceremony, as they later reported to the Jewish press: “The religious marriage was celebrated on Sunday afternoon in our Temple ... decorated for the event with exotic plants, rare flowers and valuable carpets.

All of Alessandria's high society rushed there, and the splendor was at its height. The large Temple was full, and we won't go into the list of notables and invitees who were present, because it would be too long." 144 When the community of Livorno celebrated the 250th anniversary of its Great Synagogue in 1925, over 2,300 people (more than Livorno's entire Jewish community) gathered in the synagogue grounds, and a choir composed of 160 men and children entertained the audience with hymns. The spectators included non-Jewish invitees. $^{145}$

Recent observers have criticized these changes as the erosion of authentic Judaism. The new synagogues with their choirs and organs resembled cathedrals, scholars say with a pinch of

\footnotetext{
${ }^{143}$ Il Corriere Israelitico, 1894-95, p. 179.

${ }^{144}$ End matter, Rassegna Mensile di Israel 1(2), 1925, p. VIII.

145 Toscano, "Gardens and Ghettos," 30. Dan Vittorio Segre, Memoirs of a Fortunate Jew: An Italian Story

(Bethesda, MD: Adler \& Adler, 1987), 18.
} 
disapproval. ${ }^{146}$ Rabbis dressed like priests, and sermons in the synagogue were given in Italian, not Hebrew. Certainly Italian Jews were influenced by their Catholic neighbors, but this was nothing new. European Jews did not live in a vacuum, and their Christian environment had enriched their culture for centuries. ${ }^{147}$ Besides, Italian Jews in the late nineteenth and early twentieth centuries perceived the changes as sincere improvements to their religion, not imitations of Catholicism. Moisè Soave, a Venetian rabbi and proponent of reform, said in 1865, "We wish for reform, not in order to destroy the religious sentiment, but rather to reanimate it, purify it, and render it worthy of the light of current progress." ${ }^{148}$ Salomone Olper agreed. "Religion is eternal,” he wrote in 1865, “but its regulations are changeable.", ${ }^{149}$ A year later, Rabbi Marco Tedeschi of Trieste took the same stand on translating scripture, calling Luzzatto's Italianlanguage Bible a great contribution to Italian Judaism. After all, Italian Jews were reading the Bible in Italian in any case; better they use a Jewish translation instead of the available Christian translations. ${ }^{150}$ Rabbi Ernesto Ventura in the 1930s took the same stand on reforming liturgy. “Today the mentality is different and diverse," he owned, "[but] healthier than that of old

146 Jay Berkovitz, "Acculturation and Integration in Eighteenth-Century Metz," Jewish History 24(2010): 271-273.

— The Shaping of Jewish Identity in Nineteenth-Century France (Detroit: Wayne State University Press, 1989), 217.

${ }^{147}$ Moisè Soave, L’israelitismo Moderno (Venezia: Antonelli, 1865), 11.

148 Salomone Olper, “Riforme religiose in Torino,” L’Educatore Israelita 1865, p. 129.

149 Di Giulio, "Resisting Modernity," 213. See also p. 212, 228, note 57.

150 1-14-33 Ernesto Ventura to A.Z. Idelsohn, cited in Seroussi, "Singing Modernity," 175. 
times." ${ }^{151}$ Italian Jewish reformers resembled their German counterparts in defending their decisions. ${ }^{152}$

Some Jewish customs underwent only minor changes, like circumcision (milà in Italian Jewish dialect). The majority of Italian Jews circumcised their male children in the late nineteenth and early twentieth centuries. Il Corriere Israelitico remarked in 1908 that in Rome, “only very few families refuse to do the milà to their sons,"' and reported eighteen cases of uncircumcised Jews in Mantua, out of 1,100 Jews in that town. ${ }^{153}$ Circumcision was common enough that from the 1890s to the 1920s, the Venetian Jewish prayer shawl manufacturer " M. Subert" advertised special shawls for the ritual. ${ }^{154}$ Italian Jews resembled their German brethren, most of whom observed the circumcision ceremony despite the objections of some radical reformers. ${ }^{155}$

In the rare cases that parents left their sons uncircumcised, medical concerns, not abandonment of Jewish religion, were the cause. Jewish newspapers’ defense of the ritual suggests as much. Rabbi Isaia Levi from Mantua cited medical research to explain why circumcision was healthy. "Circumcision [is] hygienic," he wrote in 1911. "[It] saves from dilapidation, rheum,

1511845 “Appeal to our German Coreligionists,” cited in Meyer, Response to Modernity, 129.

152 “Circoncisioni fatte... per forza maggiore,” Il Corriere Israelitico, 1908, p. 26. Isaia Levi, “Sulla circoncisione: ai rabbini d’Italia,” Il Corriere Israelitico, 1911, p. 210. On Mantua’s Jewish population size, see Sabatello, "HaMegamot," 254.

153 See, for instance, Il Corriere Israelitico, 1910, p. 56. Il Vessillo Israelitico, 1916, p. 284. Rassegna Mensile di Israel 1(2), 1925, p. XII.

154 Kaplan, "As Germans," 239, 248. Meyer, Response to Modernity, 123, 163.

155 Isaia Levi, “Sulla circoncisione: ai rabbini d’Italia,” Il Corriere Israelitico, 1911, p. 209. 
[and] edemas, and reduces the risks of vaccines." ${ }^{156}$ Il Corriere Israelitico published a story, most likely invented, about a little boy who falls dangerously ill. The doctor, rushes in and asks the boy’s parents: “Excuse me, but aren’t you Jewish? . . Because I can see, with the greatest surprise, that this little boy is not circumcised." He prescribes circumcision as a cure for the illness. "Really?!” exclaim the parents. "We thought we would expose him to grave danger by subjecting him to such an operation.'” Realizing their mistake, they quickly circumcise the boy and he heals perfectly. ${ }^{157}$ The pointed moral of this story suggests that the few parents who declined to circumcise their sons did so out of medical concerns, not because they distanced themselves from Judaism. ${ }^{158}$

Italian Jews observed another life-cycle event, the coming-of-age celebration. This ceremony did not disappear in the modern period. To the contrary, it expanded to include girls as well as boys. German Jews had begun celebrating girls' “confirmations,” inspired by the Catholic ceremony, in the 1810s, and French Jews held "religious initiation”' ceremonies starting in the 1840s. ${ }^{159}$ In Italy, the ceremony first took place in 1844 and became a widespread tradition by the end of the century. "For some years a gracious new female celebration has been brightening the Israelite temples - the religious initiation of girls," wrote Il Vessillo Israelitico in 1899. “It is fair

\footnotetext{
156 “Circoncisioni fatte... per forza maggiore,” Il Corriere Israelitico, 1908, p. 26.

${ }^{157}$ For an exception, see Sandro Gerbi, Raffaele Mattioli E Il Filosofo Domato (Torino: Einaudi, 2002), 75.

${ }^{158}$ Meyer, Response to Modernity, 50, 170. Michael Hilton, Bar Mitzvah: A History (London: University of Nebraska Press, 2014), 90. David Resnick, "Confirmation Education from the Old World to the New: A 150 Year Follow-Up," Modern Judaism 31, no. 2 (2011): 215-218. Berkovitz, The Shaping of Jewish Identity, 217.

159 Il Vessillo Israelitico 1899 p. 185; see also 1899 p. 221; 1900 p. 197; 1900 p. 376; 1901 p. 236; 1902 p. 385.
} 
and good that the temples welcome the girls earnestly ... as they begin to assume the rights and duties of women.",160

Through the initiation ceremony, also called maggiorità religiosa ("'religious maturity”), girls participated in Jewish public religion more than in the pre-modern period. As in France and Germany, twelve-year-old Italian Jewish girls usually celebrated as a group, on the Jewish holiday of Shavuot. ${ }^{161}$ They wore long white gowns, head garlands, and veils, similar to what Catholic girls wore at their Confirmation. The resemblance did not make the ceremony any less special however. The Jewish community of Milan held magnificent Bat Mitzvah ceremonies. “The temple was jam-packed with a massive crowd,” the community reported in June, 1919. Sixty-eight girls clad in white dresses, at their head the Jewish white-blue flag, marched onto the stage, arranged themselves in a circle around the rabbi, and chanted the Shema. They recited prayers and poems in Hebrew and Italian, and one girl played the violin accompanied by the organ. A lavish lunch followed while the synagogue band played merrily in the background. ${ }^{162}$ Luisa Almagià from Rome celebrated her confirmation in 1933. “There’s a photograph of me dressed as though I'm heading for First Communion!’’ she laughed sixty years later, realizing the irony only in her old age. ${ }^{163}$ Edda Servi from Pitigliano liked wearing the same kind of dress her Catholic

\footnotetext{
160 Byron Sherwin, In Partnership with God: Contemporary Jewish Law and Ethics ( Syracuse, NY: Syracuse University Press, 1990), 152, 163, 165-167.

${ }^{161}$ Il Vessillo Israelitico, 1919, p. 278

162 Luisa Almagià, Interview 42141 VHA Italy.

${ }^{163}$ Edda Servi Machlin, Child of the Ghetto: Coming of Age in Fascist Italy, 1926-1946 : A Memoir (Croton-onHudson: GiRo Press, 1995), 78.
} 
friends wore for their ceremonies. "Who could distinguish between a Jewish and a Christian girl? It was wonderful!'” she recalled of her own maggiorità, celebrated in $1938 .{ }^{164}$

Marriage, another life-cycle event, is often cited as proof of the abandonment of Jewish identity because of the high degree of mixed marriages. The number of unions between Italian Jews and Christians grew in the modern period, with 32 percent of Jewish men and 27 percent of Jewish women marrying non-Jewish spouses by the early 1930s. Jewish newspapers expressed anxiety at mixed marriages. To get their point across, they published novellas, printed in weekly installments, featuring young Jewish heroines who fell passionately in love with Christian men, only to find themselves deeply unhappy. ${ }^{165}$

Yet intermarriage did not necessarily lead to the disappearance of Jewish traditions. Only 15 percent of intermarrying couples chose to marry in a church, while the majority opted for civil marriages. Marrying a Catholic rarely meant converting. In Rome, home to the largest Jewish community, fewer than two Jews a year converted to Christianity between 1867 and $1934 .{ }^{166}$

Memoirs show that at least some interfaith families observed Jewish tradition. Take Rodolfo De Benedetti from Asti, born to a Jewish father and a Catholic mother in 1892. "The two religions coexisted in a reciprocal manner," recalled Rodolfo. "The fasts were observed with reasonable rigor, and so were the dietary rules of both of the religions .... We solemnly celebrated the two Passovers [Passover and Easter], but we children preferred the Jewish one for its ritual and its feasts.'” Rodolfo went to a Jewish school until third grade, and at the age of thirteen celebrated

\footnotetext{
164 Ferrara degli Uberti, Fare Gli Ebrei, Ch. 2.

165 Bachi, L'evoluzione, p. 142, table 29b, p. 186.

166 Rodolfo De Benedetti, Nato Ad Asti: Vita Di Un Imprenditore (Genova: Marietti, 1989), 48, 49.
} 
his maggiorità in the Jewish style. ${ }^{167}$ Livio, Claudio, and Lia Campi from Trieste, the children of a Christian mother and a Jewish father, also respected both religions. They went to synagogue with their father and visited the church with their maternal grandmother. They attended the Jewish nursery and the Jewish school, celebrated Rosh Hashanah at home, and fasted on Yom Kippur. ${ }^{168}$ Examples abound of interfaith families who kept elements of both religions. In Casale Monferrato, Angiolo Ottolenghi introduced his wife to others saying, "She's not Jewish, but she knows how to make kosher goose salami very well.’' His wife's religion did not prevent him from serving as president of the Jewish community. ${ }^{169}$ In Verona, some Jewish men with Catholic wives worked as employees of the Jewish community, albeit to the dismay of local rabbis. ${ }^{170}$ Guido Martinotti's Jewish mother in Milan agreed to marry a non-Jewish man on condition that the couple would raise their children as Jews. Their son attended the Jewish nursery and the first two grades of the Jewish community school, and his father paid the Jewish community taxes. ${ }^{171}$ Olga Neerman in Venice had similar memories of her Catholic grandfather Virgilio and Jewish grandmother Amelia, who raised their children as Jews. On Christmas her parents insisted that the grandchildren come to help light candles on the tree. “'One day a year,'” Virgilio pleaded with his wife, “for the sake of family peace." She agreed, except on years when Christmas coincided with

\footnotetext{
167 9-13-94 Interview with Shaul (Livio) Campi by Hana Strauss, GBA, Livio Campi folder.

168 Augusto Segre, Memories of Jewish Life: From Italy to Jerusalem, 1918-1960 (Lincoln: University of Nebraska

Press, 2008), 24.

${ }^{169}$ Miniati, Le Emancipate, 205.

170 Testimony of Guido Menahem Martinotti (cited with interviewee’s special permission), YVA, RG O.3, f. 10482.

${ }^{171}$ Neerman, Ebrei Per Caso, 33, 35.
} 
Hanukkah. ${ }^{172}$ Primo Levi’s widowed grandmother in Turin remarried to a Catholic man, and attended the synagogue and the parish church on alternate days. ${ }^{173}$

Italian Jews kept their sepulchral traditions Jewish. As in the premodern period, they maintained separate burial grounds from the Christian cemetery. Even Jews with few ties to the Jewish community were reluctant to surrender their right to be buried in the Jewish cemetery, near their loved ones, and sometimes continued to pay their community taxes only to ensure this right. In 1914, the Jewish community of Florence recognized the importance of Jewish burial for all selfidentifying Jews, and ruled that even those who left the community could arrange to be laid to rest in the cemetery, provided they paid double the entombment cost paid by community members. ${ }^{174}$ After emancipation, Jewish tombstones came to resemble neighboring non-Jewish graves. They boasted winged cherubs, bronze wreaths, and colossal mausoleums. ${ }^{175}$ Yet Italian Jews added Jewish elements as well. Stars of David were especially popular, as were biblical symbols like the Menorah or the Tables of the Covenant. Most Jewish tombstones carried inscriptions of biblical verses in Hebrew, especially ה"תנצב, standing for “may his/her soul be bound up in the bond of life’’ (paraphrasing I Samuel 25:29). Berta and Arturo Bernstein’s grave in Milan bore another favorite verse: " In life they were loved and admired, and in death they were not parted”' (II Samuel 1:23). Verses from the biblical song, “A Woman of Valor” 15 (Proverbs 31:10-31), frequently adorned women’s gravestones. For example, Adele Rocca Forti’s gravestone

\footnotetext{
172 Primo Levi, The Periodic Table (New York: Schocken Books, 1984), 16.

173 Bachi, "Il Regime," 211.

174 David Malkiel, "Modernity in the Graveyard: Jewish Tombstones from Padua, 1830-1862," Jewish Social
} Studies 19, no. 3 (2013): 90-95.

175 
in Milan suggested she gave to charity: "She opens her arms to the poor and extends her hands to the needy"' (Proverbs 31:20).

In conclusion, Italian Jewish identity in the modern period underwent extensive change and some continuities, but it did not decline. Change took place at the level of the community, which transformed its structure, legal status, and range of activity. It also took place at the level of the individual, as Italian Jews adapted, expanded, and transformed the ways in which they asserted their sense of belonging to a Jewish collective. Despite the rise of mixed marriages and the decline of pre-modern forms of religious practice such as synagogue attendance and kosher eating, Italian Jews maintained their Judaism in a variety of ways. Jewish leaders steered their communities toward a more consolidated structure, and modernized Jewish education and charity. Women assumed Jewish leadership roles, and a new Jewish press cultivated ties between Jews across the peninsula. Jews marked their difference from the non-Jewish majority, whether through culinary customs or new religious rituals. At home and in public, Italian Jews from the nineteenth century until World War II expressed a strong sense of belonging to a Jewish collective. 